\title{
STRUCTUAL AND CONTENT ASPECTS OF CORPORATE PUBLICATIONS
}

\author{
${ }^{1}$ Grigory V. Vakku, ${ }^{2}$ Anna V. Sasim, ${ }^{3}$ Svetlana E. Stepanova, ${ }^{4}$ Irina V. Zhidova, \\ ${ }^{5}$ Marina I. Vakku \\ ${ }^{1}$ Moscow state University of Humanitie, Russia, vakku2006@rambler.ru; ORCID 0000-0001-7676- \\ 8962; SPIN-код: 3886-4740; AuthorID: 284494. \\ ${ }^{2}$ FGBVOU VO "Academy of civil protection EMERCOM of Russia"; SPIN-код: 4082-4599, \\ AuthorID: 703082; anna-sasim@mail.ru \\ ${ }^{3}$ Chuvash state pedagogical University I. Y. Yakovleva, Russia; SPIN-код: 9615-5690, \\ AuthorID: 443187; clers@mail.ru. \\ ${ }^{4} 2$ nd year master's degree in Multimedia journalism at Moscow state University of Humanitie, \\ Russia; izhidova_54@mail.ru. \\ 5teacher MBOU «Gymnasium №1»Cheboksary, Russia, vakkmar@mail.ru
}

\begin{abstract}
In this article, the authors defined the concept of a corporate publication and presented the structurally meaningful features of corporate publications as a dynamic system with many components, as a general idea of the publication, as being a single indivisible emergent organism.
\end{abstract}

Keywords: corporate publications, corporate communications, corporate website, enterprise, public relations.

\section{METHODOLOGY}

Corporate publications and in-house journals are one of the corporate communications tools of a company or organization. Communication, as researchers of this topic note, helps companies adapt (or not adapt) and respond to events in the outside world. Strategically, corporate communications serve to the benefit of the organization and fulfill the goals set by its shareholders.

The purpose of this article is: to analyze the structurally meaningful aspects of corporate publications.

The following methods are used: typological analysis, comparative analysis and document analysis.

\section{THE REZULTS OF THE STUDY}

Corporate publications and in-house journals are one of the corporate communications tools of a company or organization. Communication, as the researcher D. Cornelissen notes, helps organizations adapt (or not adapt) and respond to events in the outside world. Strategically, corporate communications serve to the benefit of the organization and fulfill the goals set by its shareholders (Agafonov, 2008).

Corporate print media is a specific form of business communication that has all the characteristics of the 
media and is used as a tool for managing the company and developing a corporate culture, helping to increase the efficiency and profitability of the business. The Federal Agency for Press and Mass Communications of the Russian Federation classifies corporate publications as "industry-specific, highly professional publications - print media whose contents are of interest only to persons professionally associated with a certain industry or area of management, production, commercial activities etc (Budnichenko, Vakku, 2016)."

By corporate publication we mean a periodical (print or electronic) that expresses the sectoral interests of the basic PR subject and meets the goals of creating its positive image and increasing the publicity capital. Yu.V. Chemyakin defines a corporate publication as "a periodical printed publication, radio, television, video program, Internet website, intranet portal, or other form of periodic dissemination of information that serves the interests of a particular corporation, created on its own initiative and intended, as a rule, for people related to this corporation (7)."

Let's take a short digression into history and recall that "internal leaflets" or bulletins for workers (Germany, 1830) issued by F. Liszt; the HazelTs Magazine for workers of Hazell, Watsell and Viney (the UK, 1860); and the first corporate journal, Furrow (the USA, 1895), can be considered some of the first examples of corporate publishing. A corporate publication is sometimes called a newsletter, which is a corporate newspaper or bulletin. The origins of such publications in Russia lie in the factory press. "Large-circulation newspapers (factory newspapers) are the Soviet predecessors of the corporate press. The Great Soviet Encyclopedia states that "the experience of the active participation of workers in the issue of thousands of factory wall newspapers led to the appearance of the first printed factory and plant newspapers in 19221925". The term "large-circulation press" reflected the fact that the first publications of this type were created on the basis of wall newspapers by replicating them using a hectograph - a printing press." Obviously, the word "large circulation" originated from there: compared to a single copy of a wall newspaper, even a circulation of several tens or hundreds of copies - this, of course, was considered large" (Cornelissen, 2004). Thus, the first corporate publications in Russia in the modern sense include Gazprom Magazine, Direct Investments journal by Sberbank RF, Aeroflot Magazine and others.

In today's world practice corporate publications are the company's key channel of communication with its internal public, partners, customers and professionals. Electronic corporate media has become more popular. So in 2012 Coca-Cola reorganized Coca-Cola Journey, its corporate publication for employees, and turned it into the electronic media for consumers. Pepsi did the same by reformatting its website into Pepsi Pulse. This type of press is also actively developing in Russia and is reaching the level of external communications. According to experts, the annual turnover of the corporate publications market in modern Russia is approaching one billion dollars.

A corporate publication of any format as a universal tool for managing the company meets the multisectoral interests of the founder and solves many problems, such as: it informs the target audience about the policies, opinions and leadership positions of the company; helps to increase the company's publicity capital; forms a close-knit team, builds the team spirit, corporate culture, philosophy and ideology; manages (creates and adjusts) the corporate image and reputation - serves as an image advertising tool; notifies the public about the results achieved, the success of the team and specific employees, development prospects; positions the company, promotes the company and its products on the market, strengthens the brand or trade mark; forms public opinion, informs the consumer about the directions and specifics of the company's activity; promotes educational activities, employee training, development of the company and its personnel, the dissemination of best practices, the implementation and strengthening of corporate values; establishes a trusting environment between employees, consumers and partners; serves as a tool for resolving conflicts and communication problems within the company, as well as for mobilizing, consolidating employees, etc.

The conceptual model of a corporate publication includes the following components:

- Ideological: architectonics of publications, their thematic model, headings, general structure, reflecting the mission, values, principles, goals, objectives, relations with the founders;

- Typological: the status, characteristics, target audience, frequency, distribution area of publications, contents and literary and artistic forms of corporate publications, genre structure;

- Organizational and managerial: the chief editor, editorial staff, its structure, functional subordination, management style and principles;

- Composition and graphics: the graphic design and structure, use of corporate identity, symbols, principles of illustration, color scheme, publishing and printing design of a publication, its volume, circulation, format;

- Facilitative: methods of collecting and processing information, sources of information, collective analysis of 
information (including legal) and their effectiveness for the audience, the leading page, editorials, content and placement of advertisements, illustrations;

- Economic: financing, economic management;

- Technological: manufacturing technology (risography, offset printing, digital printing, etc.), paper selection, printing method;

- Marketing (for the external environment): the place and role of the publication in the media market (Petropavlovsk, 2015).

Information and marketing control is one of the advantages of a corporate publication, as it allows to fully control information about the company, its strategic plans, markets, interaction with consumers and employees.

Let us consider the classification of corporate publications and present methods for their typology in Tab. 1.

Tab. 1 - Methods of typology of corporate publications

\begin{tabular}{|l|l|}
\hline \multicolumn{1}{|c|}{ Classification } & \multicolumn{1}{c|}{ Characteristics } \\
\hline $\begin{array}{l}\text { By distribution methods and } \\
\text { channels }\end{array}$ & $\begin{array}{l}\text { - printed (newspaper, magazine, collection, newsletter, catalogue, } \\
\text { almanac, information board, information sheet, etc.); } \\
\text { - electronic (website, intranet portal, electronic versions of newspapers } \\
\text { and magazines, radio, television, blogs, etc.). }\end{array}$ \\
\hline By type of target audience & $\begin{array}{l}\text { - for employees (B2P, business-to-personnel); } \\
\text { - for clients, consumers (B2C, business-to-client, business-to-consumer); } \\
\text { - for business partners (B2B, business-to-business); } \\
\text { - for professionals (B2Pr, business-to-professional); } \\
\text { - for government bodies (B2G, business-to-government). }\end{array}$ \\
\hline By type of financing & $\begin{array}{l}\text { - fully subsidized (at the expense of the founder); } \\
\text { - partially self-supporting; } \\
\text { - self-supporting; } \\
\text { - profitable. }\end{array}$ \\
\hline $\begin{array}{l}\text { By the degree of } \\
\text { independence during the } \\
\text { preparation and publication }\end{array}$ & $\begin{array}{l}\text { - published by the company (by the company's own personnel); } \\
\text { - published with the help of subsidiaries; } \\
\text { - published in outsourcing (using an external source) }\end{array}$ \\
\hline
\end{tabular}

Most modern corporate publications in Russia are fully subsidized. Some publications (primarily those of large corporations) earn some of the money themselves - mainly by attracting advertising, and also (sometimes) by selling the circulation. There are still very few fully self-supporting corporate media and profitable publications in our country. Financing depends on the volume of publication, its frequency and method of publication (in-house or using outsourcing).

It should be noted that Yu.V. Chemyakin identifies such a type of publication as "On-board magazines" ("onboard publications", "passenger magazines") which are corporate publications intended for customers of transport companies (passengers), usually distributed on planes or trains (Cornelissen, 2004).

Let us further consider the functions of corporate publications. These functions are affected by many factors, one of which is the target audience. Thus, the functions of internal publications will be significantly different from the functions of corporate publications for an external target audience (Petropavlovsk Yu, 2015).

Intra-corporate publications have the following main functions:

1) The ideological function is aimed at creating a corporate culture;

2) The information and communication function is aimed at collecting information for the company's 
management on the development of production and acute problems of a production or social nature;

3) The integration function is aimed at the exchange of information and opinions through the corporate media, it contributes to the creation of an atmosphere of unity and cohesion in the working team;

4) Educational function can be an important tool to improve the professional competencies of the company employees;

5) The entertainment function allows readers to relax and take a break, so some crosswords, scanwords and jokes, as well as anecdotes of workers are published on the last page (Sakharov A. V., Baryshev, 2018).

Corporate publications aimed at the external target audience have the following functions: the commercial function helps to attract new clients as well as retain existing customers and business partners of the company; the image-building function helps to create a positive image of the company, arouse trust and help make confident choice; the integration function helps bring together customers, business partners of the companies, stock market analysts, investors, etc .; the information and communication function is a means of informing readers about the company's products and services, about its successes, and industry development trends (Semyonova, 2017).

Such multi-functionality of modern corporate publications is due to economic, social, technological and other factors, as well as the informatization of society.

Speaking about the holistic concept of corporate publications, we can name the main types of printed and electronic corporate publications and show their characteristics in Tab. 2 (Rezvanov R. I.).

The content, rubrication, thematic nature of newspaper articles are determined by the ideological orientation and mission of a particular corporate publication, the practical objectives of the company management and the needs of employees.

Tab. 2 - Main types of print and electronic corporate publications

\begin{tabular}{|l|l|}
\hline \multicolumn{1}{|c|}{ Type } & \multicolumn{1}{|c|}{ Characteristics } \\
\hline Newsletter & $\begin{array}{l}\text { a small and common publication whose purpose is to inform the } \\
\text { public in a special context and at the right time }\end{array}$ \\
\hline Newspaper & $\begin{array}{l}\text { being a traditional type of publication, it is issued regularly and has } \\
\text { a clear structure, theme and content. It solves many tasks of team } \\
\text { building and informing an external audience. }\end{array}$ \\
\hline Magazine & $\begin{array}{l}\text { also being issued regularly, it contains some news about the } \\
\text { company and its products and about its partners, as well as some } \\
\text { image articles, analytical reviews, expert opinions, entertainment } \\
\text { elements, etc. }\end{array}$ \\
\hline Comics & $\begin{array}{l}\text { a rare, unusual, but interesting and recognized by the target } \\
\text { audience corporate publication, the purpose of which is not only to } \\
\text { entertain, but also advertise and promote the product. These } \\
\text { publications are very popular in the USA, Europe, Japan, therefore } \\
\text { they are often translated into Russian, but nowadays comic book } \\
\text { culture is developing in Russia as well. They are not published } \\
\text { regularly; they are published on printed and electronic media. }\end{array}$ \\
\hline $\begin{array}{l}\text { Marketing publications (catalogue, } \\
\text { leaflet, booklet, almanac, } \\
\text { prospectus, calendar) }\end{array}$ & $\begin{array}{l}\text { presentation publications of the image nature presenting the } \\
\text { product or service of the company }\end{array}$ \\
\hline On-board publications & $\begin{array}{l}\text { for passengers (of aircraft, trains, ships), containing materials about } \\
\text { the company and the product both of general and entertaining } \\
\text { nature }\end{array}$ \\
\hline Reports & $\begin{array}{l}\text { annual reports on the company's activities for its shareholders, } \\
\text { consumers of goods and services, investors, periodicals and public }\end{array}$ \\
\hline
\end{tabular}


IJASOS- International E-Journal of Advances in Social Sciences, Vol. VI, Issue 16, April 2020

\begin{tabular}{|l|l|}
\hline & authorities \\
\hline Information board & for internal announcements and information \\
\hline $\begin{array}{l}\text { Electronic corporate publications: } \\
\text { the Internet website, intranet portal, } \\
\text { electronic version of a newspaper, } \\
\text { magazine, corporate radio, video, } \\
\text { as well as Web-TV, blogs, etc. }\end{array}$ & $\begin{array}{l}\text { The market share of such publications is growing rapidly and this is } \\
\text { also driven by social and temporal factors. }\end{array}$ \\
\hline
\end{tabular}

As a rule, the theme of the publication reflects the activities of the company, meets its goals and mission and mainly addresses the following topics:

- Company and market news;

- Launch of new products, the company's achievements, merits, awards;

- Interviews with top managers and leading employees;

- Corporate social responsibility;

- Strategic plans and prospects of the company;

- Discussion of current issues;

- Exchange of professional experience and expertise (Vakku, Malygina, 2019).

The content of corporate publications is subject to the general laws of the system of headings:

- Front-page: top-level corporate news, descriptions of key events, industry news directly related to the company. It is believed that there should be a "cover story", the most important material with a large qualitative illustration, information about the company's performance indicators - numerical information (for example, percentage of sales, stock quotes, growth in the number of branches, number of employees, etc.). The theme of each individual issue is especially important if the newspaper is rarely published, for example, once a month or even less often;

- The second page should contain the continuation of the main material from the front page; the second tier corporate news including an interview with one of the managers on the relevant topic, covered in the news section of the editorials;

- The third page is practical: description of innovations introduced in the company; workshops and case studies from experienced employees and managers, success stories of employees, presentations of new team members, information about the career growth of employees, changes in company management;

- The fourth page contains entertaining materials. It often contains useful tips (within the framework of corporate culture), reports of the company's sports, cultural, recreational events, team building activities, etc., which are always accompanied by photos (Shemyakin, 2006).

\section{CONCULUSION}

Thus, we defined the concept of a corporate publication and presented the structurally meaningful characteristics of corporate publications as a dynamic system with many components, as a general idea of the publication, a single indivisible emergent organism.

The objectives of corporate publications do not include material benefits, and their purpose is not related to profit-making. Nevertheless, serving the needs of the corporation and being a PR "tool", corporate publications help to create a corporate culture, promote the company brand and improve interaction and communication with clients and employees of the company.

The content, system of headings, thematic nature of corporate publications are determined by the ideological orientation and mission of a particular corporate publication, the practical objectives of the company management and the needs of employees.

Corporate publications, in the first place, exist to reflect the interests of a particular founding corporation, to facilitate its development and relations with company counterparties. The purpose of the publication and the content which meets this purpose are discussed in the next section.

In the last decade, print and electronic corporate publications have been actively developing and 
transforming. The prospects for the growth and improvement of corporate publications indicate that in the near future this trend will intensify, and we will see innovative corporate media projects, foresight media.

\section{REFERENCE LIST}

1. Agafonov. (2008). Agafonov, L. S. Corporate press: peculiarities of functioning, typological characteristics and methods of efficiency evaluation: dis...Cand. Philol. Sciences [Text] / L. S. Agafonov. - Moscow. 2008.

2. Budnichenko, Vakku. (2016) Budnichenko L. A., Vakku G. V., Image advertising in the regional media space // Information field of modern Russia: practices and effects: Collection of articles of the XIII International scientific and practical conference, 20-22 October 2016./ edited By R. p. Bakanov. Kazan: Kazan publishing House. UN-TA, 2016. - s. 136-144.

3. Cornelissen. (2004). Cornelissen, J. Corporate communications: a guide to theory and practice. - London: SAGE Publications, 2004. - s. 20-21

4. Petropavlovsk. (2015). Petropavlovsk, Yu. a. Corporate publications as a variety of Madia: access to a mass audience [Text] / Yu. Petropavlovsk / / Bulletin of the Moscow state University, series 10: Journalism. - 2015. - .Vs 5. Pp. 43-49.

5. Petropavlovsk Yu. (2015). Petropavlovsk, Yu. Features of creation of the concept of corporate edition [text] / Yu.a. Petropavlovsk / / Bulletin of Kemerovo state University. - 2015. - No. 2-4 (62). Pp. 68-72.

6. Rezvanov R. I. Time plays on corporate media [Text] / R. I. Rezvanov / / State service. - 2016. - No. 4 (102). Pp. 34-39.

7. (Research). Research of the Association of Directors for communications and corporate media of Russia. URL: www.amr.ru/upload/iblock/44b/44b3353578f2598dd2965303f7309113

8. Vakku, Malygina. (2019). Vakku, G., Malygina, L., Klushina, N., Baranova, E., Lazutova, N. Features of the submission of news content on regional television in Russia // Amazonia Investiga. - 2019. - No. 8 (23). - P. 861-867.

9. Sakharov A. V., Baryshev. (2018). Sakharov A. V., Baryshev V. V., G. V. The Vacca. Press services of sports organizations // Dynamics of relations between different fields of science in modern conditions: science.- pract. Conf. (Chelyabinsk, January 30, 2018) - Sterlitamak: "AMI". 2018. Part 2. Pp. 135137.

10. Semyonova. (2017). Semyonova L. M. the Concept of a holistic concept of corporate publishing / L. M. Semyonova / / journal "Sign: problem field of media education". - 2017. - No.2(24). - Pp. 99-106.

11. Shemyakin. (2006). Shemyakin, Yu. V. Corporate media: the secrets of efficiency [Electronic resource] / Yu Chemiakin. - Ekaterinburg: publishing house "Discourse PI". - 2006. - URL: http://samzan.ru 230612.

\section{Authors}

1. Vakku, Grigory Vladislavovich - candidate of philological Sciences, associate Professor, associate Professor of the Department of Russian language, literature and journalism at Moscow state University of Humanitie, Build. 49, 401, Losinoostrovskaya str. Moscow, 107150, Russia; e-mail: vakku2006@rambler.ru ORCID 0000-0001-7676-8962; SPIN-код: 3886-4740; AuthorID: 284494

2. Sasim Anna Viktorovna-candidate of philosophy, associate Professor of the Department of advertising and public relations fgbvou VO "Academy of civil protection EMERCOM of Russia", 141435, Moscow region, Khimki, MD. Novogorsk, FGBVOU VO "Academy of civil protection of EMERCOM of Russia", e-mail: annasasim@mail.ru SPIN-code: 4082-4599, AuthorID: 703082

3. Stepanova, Svetlana Evgenievna - candidate of philosophy, associate Professor, Department of communication technologies and management, "Chuvash state pedagogical University I. Y. Yakovleva», 428000, Chuvash Republic, Cheboksary, ul. K. Marx, 38. e-mail: clers@mail.ru SPIN-код: 9615-5690, AuthorID: 443187

4. Irina Vladimirovna Zhidova, 2nd year master's degree in Multimedia journalism at Moscow state University of Humanitie, Build. 49, 401, Losinoostrovskaya str. Moscow, 107150, Russia; e-mail: 
izhidova 54@mail.ru

5.Marina Ivanovna Vakku, teacher MBOU «Gymnasium №1» Cheboksary, Russia, vakkmar@mail.ru. Cheboksary, 24, Elgera str., Cheboksary, Chuvash Republic, Russia, 428025. Russia, vakkmar@mail.ru 